\title{
Overloaded Overheads: Activity-Based Cost Analysis of Material Handling in Cell Manufacturing
}

\author{
SRIKANT DATAR** \\ SUNDER KEKRE* \\ Tridas MuKHOPADYAY* \\ ERIC SVAan ${ }^{\dagger}$
}

\section{EXECUTIVE SUMMARY}

Manufacturing managers today are pressed by aggressive international competitors, high input factor prices, and customers who demand better quality at lower cost. In such an environment, there is a growing need to exploit the time, cost and quality advantages of cell manufacturing (Hyer and Wemmerlöv (1984)). Unfortunately, traditional cost accounting systems may be a major roadblock on the highway to future manufacturing competitiveness. These systems may stifle manufacturing initiatives to improve process design by providing inaccurate cost information. They may also send the wrong signals to managers who must evaluate the cost/benefit impact of process innovation (such as cells and group technology implementation), thereby causing companies to retain outmoded, inefficient manufacturing practices.

We discuss the results of our field study which illustrates the use of activity-based costing $(A B C)$ to quantify the benefits of cell manufacturing and synchronized process flows. Auto Light Company, a Fortune 500 automobile components manufacturer, had begun to replace its functional layout with synchronous manufacturing cells. Although dramatic progress had been made in operational measures (such as throughput time, work-in-process (WIP) inventories. and material flow distance), existing accounting systems failed to trace these savings to the source, namely the change in manufacturing practices. Overheads were being allocated to products on the basis of direct labor or machine hours. which at Auto Light are no different in cells than in traditional manufacturing.

A joint Auto Light management/Carnegie Mellon University team examined the impact of cell manufacturing on major cost categories. The group identified material handling expenses (which exceed $\$ 5,000,000$ per year, and comprise approximately $10 \%$ of total factory costs) as a promising area for analysis using $\mathrm{ABC}$ principles. We sought to identify relevant material handling cost drivers: that is, activities that (1) create costs and (2) seem reasonable to use as proxies for assigning costs to products. Interviews, plant records and time-and-effort studies pointed to "number of moves" and "distance moved" as key drivers of material handling costs. Annual production volumes, physical dimensions of products and their production routings were used to calculate the number of moves, and the distance

\footnotetext{
Manuscript received March 15, 1990; accepted by Urban Wemmerlöv on January 22, 1991, after two revisions.

*Carnegie Mellon University, Pittsburgh, Pennsylvania 15213

**Stanford University, Stanford, California 94305

†University of Michigan, Ann Arbor. Michigan 48109
} 
required for each move, for each production part. Department cost accounts pertaining to three stages of material handling (purchased parts, WIP and finished goods) were used to fill two cost pools for each stage, making a total of six material handling cost pools. These cost pools were then allocated to each part based on the drivers, i.e., number of moves and the distance moved. The result was a new cost for each part, an improved (we believe) estimate of the cost of material handling.

Although rigorous proof of the superiority of one accounting scheme over another is impossible, our revised material handling costing system has obvious intuitive appeal. Its major strength is that it traces material handling costs to products based on measures that are related to the material handling activity. In contrast, the old accounting system allocates costs based on measures related to manufacturing activity (labor and machine hours). It seems obvious to us that parts identical in labor and machine-hour but differing vastly in material handling required should be charged differently for that material handling. On this basis we will characterize differences between our revised (and, we believe, more accurate) costs and the old costs as distortions of the existing system.

Our next analysis examined the relationship between machine hours (the old allocation basis) and the new cost, calculated using the two driver approach. As expected, the correlation we found was poor $\left(R^{2}=.40\right)$. This result indicated that the existing basis for allocation of material handling costs was significantly different from our two-driver basis. Furthermore, we found that products responsible for $70 \%$ of the costs by our calculation were being charged $30 \%$ of the allocations under the existing system. Conversely, products responsible for $30 \%$ of the costs were being charged $70 \%$ of the allocations. Included in this latter category of overcharged products were those manufactured in cells. When we examined a typical cell product we found that the distortion was extreme, overstating the material handling cost by an order of magnitude. Likewise, purchased parts obtained from certified vendors which required no incoming inspection and therefore saved on material handling were not credited with the resulting cost savings.

These distortions obscured the extremely positive effects on costs of rationalized process flow through cell organization. Distorted costs could lead managers to decide against adoption of cells, and thereby commit Auto Light Company to retain the existing complex, expensive process flow pattern over the long term-a recipe for disaster. In the interim, cost distortions leave the overcosted portions of Auto Light's product line vulnerable to attack by competitors with more accurate accounting systems. Our activitybased costs send more accurate signals to management concerning current costs. In addition, activitybased costs highlight the opportunity to realize additional costs savings by investment in cell manufacturing and synchronized process flows.

Our analysis quantified the potential for actual dollar savings, which could come from reductions in material handling labor force, equipment, supervision etc. Although such reductions are difficult to make and impossible to measure in the short term, they may be realized through aggressive management action. The activity-based costing system more accurately identifies the opportunity areas for process improvement, and thereby supports effective managerial decision making concerning technology investment and cell manufacturing implementation.

\section{INTRODUCTION}

Activity-based costing ( $\mathrm{ABC}$ ) seeks "to understand better the factors that create the demand for overhead and support resources and then to assign the costs of those resources based on the demand made by individual products' (Kaplan and Atkinson (1989)). ABC has been applied in various company contexts to improve product cost structures, rationalize pricing, and make better production lot-sizing decisions (e.g., March (1987), Kaplan (1990) and the special issue of the Journal of Cost Management, Spring 1990 (Cooper 1990)). Feature-based product costing (Banker, Datar, Kekre, and Mukhopadyay (1990)) has extended ABC principles to give guidance to design engineers concerning the demands on productive resources created by product features. A new application area for ABC (e.g., Cooper and Turney (1990) and Jaikumar (1990); see also Berlant, Browning and Foster (1990)) presented in this paper is in the design and analysis of process flows, specifically those in advanced manufacturing contexts of cells and group technology (GT). In contrast to the product-based applications, process-oriented use of 
$\mathrm{ABC}$ is not chiefly concerned with evaluating the costs incurred by specific products. Rather, the focus is on economic modeling of process flows, with a view to enabling improved managerial decision making concerning the adoption of cells and group technology.

\section{BASICS OF ACTIVITY-BASED COSTING}

Activity-based costing (the term was first used by John Deere (Kaplan (1989)) is a recent development in management cost accounting. It represents a "middle way" between the small number of cost pools characteristic of traditional labor-based or machine-hour allocation systems, and the overwhelming number of measurements and individual cost pools needed to calculate and charge truly accurate costs to cach product. Its principles and history have been clearly explained in a series of articles by Robin Cooper in the Journal of Cost Management, titled "The Rise of Activity-Based Costing"' (Cooper (1988)). The last article in this series and other articles in the same journal (e.g., Shank and Govindarajan (1988)) give examples of the use of $\mathrm{ABC}$ systems in manufacturing.

Product cost information is fundamental to manufacturing management (Cooper and Kaplan (1988)). Effective managerial decision making is difficult, if not impossible, when it is based on costing systems replete with distortions. Many traditional cost accounting systems, many of whose conventions were adapted 50 years ago to support the valuation of inventory (Johnson and Kaplan (1987)), are not capable of sending reliable signals for optimal management decision making in contexts of wide product diversity (Foster and Gupta (1990)).

Labor-based overhead allocation is a typical feature of traditional accounting systems. Under its conventions, manufactured products are charged with direct material and direct labor used in their production. All other factory costs, including the factor inputs listed above and also building expenses, utilities, management salaries, etc. are consolidated into one or more overhead cost pool(s). This figure is typically divided by the projected annual labor dollars, or annual machine hours, to obtain a standard overhead allocation rate. Each product is allocated a share of the overhead calculated as the product of its direct labor cost (or machine hours) and the standard overhead rate.

This system, in fact any reasonable system, works fairly well under conditions of product homogeneity. Its weaknesses are revealed in high variety manufacturing settings. Technological changes in design, production and information processing equipment mean that a diminishing share of manufacturing value is added by direct labor, with other factors increasing correspondingly. These other factor inputs, such as indirect materials, capital equipment, information systems, planning and control functions, material handling, research and development, marketing, accounting, personnel, manufacturing engineering, etc. often dominate direct labor costs by as much as an order of magnitude, and require more sophisticated accounting modeling than do dircet labor costs (Cooper, Sinha and Sullivan (1990)).

In such environments the costs of diverse resources demanded by many different products cannot be fairly allocated by a single basis factor (labor or machine hours). This is particularly true of high-technology businesses, where the overheads dominate the plant cost structure. A high-technology plant in which one of the authors worked had an overhead rate of $800 \%$, just prior to abandonment of labor-based costing. In other words, each dollar of direct labor applied to a product carried along with it eight dollars of overhead expenses. This rate was applied regardless of whether the product was a simple one with high direct labor content, or a hightechnology product produced automatically. High-tech products are typically manufactured with little or no direct labor, on extremely capital-intensive equipment requiring extensive engineer- 
ing support and frequent skilled maintenance. When these products are produced side-by-side with low-tech products, and overheads are naively allocated, distortions are introduced.

$\mathrm{ABC}$ accounting deals with the facts of high-technology life by breaking down an aggregated overhead cost pool into as many lower-level cost pools as are necessary to distinguish the cost effects of different products. A detailed illustration of the application of these principles is found in Berlant, Browning and Foster (1990). Product features that create costs, called "cost drivers," are identified. Only the products demanding supporting activities are charged, in proportion to the quantities of the "drivers" that the products consume.

For example, suppose that Auto Light produces only products A and B, one million units of each, as shown in Table 1.

\section{TABLE 1}

AUTO LIGHT MATERIAL HANDLING

\begin{tabular}{lrrr}
\hline & Prod A & Prod B & Total \\
\hline Annual machine hours & 10,000 & 10,000 & 20,000 \\
Annual DL* hours & 10,000 & 10,000 & 20,000 \\
Hourly DL cost & 10 & 10 & 10 \\
Annual DL cost & 100,000 & 100,000 & 200,000 \\
Annual volume & $1,000,000$ & $1,000.000$ & $2,000,000$ \\
Machine Hours/unit & 0.010 & 0.010 & 0.010 \\
DL cost/unit & 0.10 & 0.10 & 400.000 \\
Annual DM* cost & 200.000 & 200,000 & \\
DM cost/unit & 0.20 & 0.20 & \\
Unit direct cost & 0.30 & 0.30 & \\
Unit indirect cost (exc. MH*) & 0.40 & 0.40 & \\
(Direct + indirect)/unit & 0.7 & 0.7 & 400,000
\end{tabular}

$* \mathrm{DL}=$ Direct Labor, $\mathrm{DM}=$ Direct Material, $\mathrm{MH}=$ Material Handling

Scenario 1: Current Material Handling Allocation [Machine Hours Based]

\begin{tabular}{lrrr}
\hline & Prod A & Prod B & Total \\
\hline Material Handling costs & & & 400,000 \\
MH costs/machine hour & & & 20.00 \\
MH costs/unit & 0.20 & 0.20 & \\
(Direct + indirect)/unit & 0.7 & 0.7 & \\
Total cost/unit & 0.90 & 0.90 &
\end{tabular}

Scenario 2: Activity-Based Material Handling Allocation [Driver Based]

\begin{tabular}{lrrr}
\hline & Prod A & Prod B & Total \\
\hline Annual volume & $1,000,000$ & $1,000,000$ & $2,000,000$ \\
Annual \# of trips & 100.000 & 400,000 & 500,000 \\
Trips/unil & 0.10 & 0.40 & 400,000 \\
Matcrial handling costs & & & 0.80 \\
Cost/trip & 0.08 & 0.32 & \\
MH cost/unit & 0.70 & 0.70 & \\
(Direct + indirect)/unit & 0.78 & 1.02 & \\
Total cost/unit & & &
\end{tabular}

Market Conditions: Competitor's Pricing 


\section{TABLE 1 Continued \\ AUTO LIGHT MATERIAL HANDLING}

\begin{tabular}{|c|c|c|c|}
\hline & $\begin{array}{r}\text { Prod A } \\
0.80\end{array}$ & $\begin{array}{r}\text { Prod B } \\
1.05\end{array}$ & \\
\hline \multicolumn{4}{|l|}{ Income statement } \\
\hline Revenue & Prod A & Prod B & Total \\
\hline $\begin{array}{l}\text { Price/unit } \\
\text { Annual Volume }\end{array}$ & $\begin{array}{r}0.85 \\
1,000,000\end{array}$ & $\begin{array}{r}1.05 \\
1.000,000\end{array}$ & $2,000,000$ \\
\hline Sales & $\$ 850,000$ & $\$ 1,050,000$ & $\$ 1,900,000$ \\
\hline Cost of Sales_-Current System & Prod A & Prod B & Total \\
\hline Direct costs/unit & 0.30 & 0.30 & \\
\hline Indirect costs/unit & 0.40 & 0.40 & \\
\hline Material handling costs/unit & 0.20 & 0.20 & \\
\hline Total costs/unit & 0.90 & 0.90 & \\
\hline Annual Volume & $1,000,000$ & $1,000,000$ & \\
\hline Cost of Goods sold & $\$ 900,000$ & $\$ 900,000$ & $\$ 1,800,000$ \\
\hline Net Income (Loss) & $(\$ 50,000)$ & $\$ 150,000$ & $\$ 100,000$ \\
\hline Cost of Sales-Activity Based & Prod A & Prod B & Total \\
\hline Direct costs/unit & 0.30 & 0.30 & \\
\hline Indirect costs/unit & 0.40 & 0.40 & \\
\hline Material handling costs/unit & 0.08 & 0.32 & \\
\hline Total costs/unit & 0.78 & 1.02 & \\
\hline Annual Volume & $1,000,000$ & $1,000,000$ & \\
\hline Cost of Goods sold & $\$ 780,000$ & $\$ 1,020,000$ & $\$ 1,800,000$ \\
\hline Net Income (Loss) & $\$ 70,000$ & $\$ 30,000$ & $\$ 100,000$ \\
\hline
\end{tabular}

Product $\mathrm{A}$ is a product requiring minimal material handling. Direct fabrication costs (labor and materials) for product $\mathrm{A}$ are $\$ 0.30$ per unit. Product $\mathrm{B}$ is a product whose fabrication process and direct costs are identical to that of product $\mathrm{A}$, but which requires four times as much material handling effort. The full annual cost of the material handling operation (including all wages, salaries, utilities, depreciation, occupancy expenses, etc.) is $\$ 400,000$. The department is used only for moving products A and B, and its capacity is fully utilized. All material handling trips take the same time, the same equipment, and cover the same distance. $\mathrm{ABC}$ accounting would charge products A and B with the costs associated with the material handling operation, based on the relevant cost driver "number of trips," at $\$ 0.08$ for each unit of A and $\$ 0.32$ for each unit of B. In contrast, traditional costing systems would unfairly penalize units of product A by charging them (on the basis of their machine hours) with a superficially "equal," but in fact disproportionately large, share of the material handling costs $(\$ 0.20$ per unit). This would lead (based on the annual volume) to an additional $\$ 0.12$ per unit being unfairly allocated to the factory cost of product A.

In a highly competitive market in which the prices shown in Table 1 hold, this apparent cost disadvantage might cause management to discontinue production of product A. Management 
will classify product A as "uncompetitive"' and product B as "highly profitable," as shown in Figure 1. In truth, both are marginally profitable, with product $A$ contributing $\$ 0.07 /$ unit and product $B$ contributing $\$ 0.03 /$ unit. If management decides to drop product $A$ from its line, it will find itself with only product B to absorb its overheads, including the costs of its material handling operation. Even if the costs formerly borne by $\mathrm{A}$ can be cut, the bottom-line profitability of the firm is reduced from $\$ 100,000$ to $\$ 30,000$.

\section{FIGURE 1}

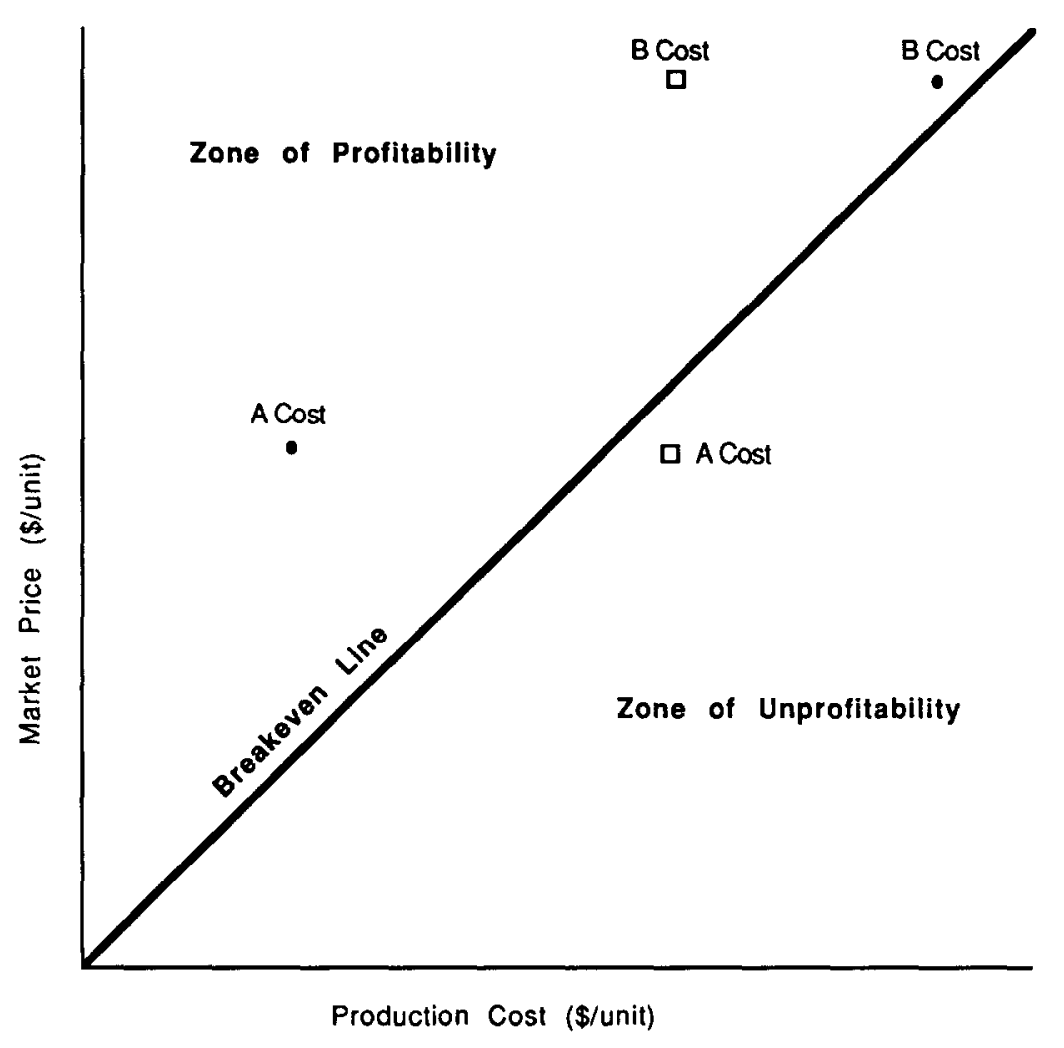

- Activity Based Cost

口 Traditional Cost

If $\mathrm{ABC}$ costing had been used, the positive profit contribution of both products would be identified, and both would be retained. A company using $\mathrm{ABC}$ is thus less vulnerable to attack by aggressive smaller companies who could otherwise take advantage of distortions in cost allocations to "cherry-pick" apparently unprofitable (but actually profitable) product lines from its portfolio, leaving it with reduced volumes of mismatched products. 
This scenario is not merely theoretical at Auto Light. A consultant group studied its costs (as recorded by its accounting systems) and compared them to market prices for similar products. In a portion of the product line, Auto Light owned the most advanced technology in the world and essentially had no competition. Where Auto Light did not enjoy this technological advantage, the consultants classified several products as non-competitive, and many others as marginally competitive. In many cases it appeared that simpler products, which by their simplicity were natural candidates for cell manufacturing, were uncompetitive according to conventional accounting. It is a fact that several customers have begun to procure lighting products from vendors other than Auto Light, citing lower prices as the reasons for switching their business. The probability is great that, among the hundreds of products in Auto Light's lineup, some are being priced out of the market by accounting distortions.

\section{COMPANY BACKGROUND}

Auto Light Company is a division of a Fortune 500 automobile parts manufacturing company. Historically most of its sales went to sister divisions in the company. As a captive supplier, it has to some extent been insulated from strong competitive and cost pressures. However, in the past decade foreign competitors have damaged the market share of the parent corporation. The resulting volume declines led to hard times for Auto Light, making lengthy layoffs necessary in most recent model years. On top of this, its customer divisions are now demanding that Auto Light bring prices into line with a new group of competitors who are clamoring for business. Many of these competitors are smaller, non-unionized operations who underprice Auto Light on a subset of its product line. To date the customer divisions have remained mostly loyal, but the threat that they might take their business elsewhere remains. Divisional staff are concerned that the portions of the business under attack might actually be among their most profitable lines, although the data on this point is not clear. What is clear is that the full range of automotive lighting products that Auto Light supplies to its customers created a large staff, multiple departments, complex product flows, and complex communication patterns with resulting high overheads. Any loss of volume poses serious threats to overhead absorption that would be very uncomfortable for Auto Light to face.

\section{CELL MANUFACTURING STATUS}

Cell manufacturing at Auto Light is the culmination of several steps away from traditional large-batch manufacturing practices with attendant long lead times, large travel distances and high levels of work in process (WIP) inventory. The company began experimenting with "synchronous manufacturing", practices in 1987. Significant reductions in inventory and manufacturing flow time were achieved. But the sheer complexity of material flows of well over 1000 finished products, and customer demand for lower cost and faster response (Stalk (1988)), led management to experiment with group technology via manufacturing cells. (See Hyer and Wemmerlöv (1984) for discussions of GT and cell manufacturing advantages and Hyer and Wemmerlöv (1989), Wemmerlöv and Hyer (1989) for current practice in United States manufacturing.)

The establishment of cells means a break with traditional manufacturing at Auto Light. Existing equipment and processes are arranged generally according to function. Plastic injection molding, painting, plating, metallizing, hot stamping, welding, and assembly operations each occupy a distinct section of the plant. The plant area exceeds one million square feet. Typical 
material flow distance between manufacturing process exceeded 5000 feet, with movements between productive departments assigned to an army of schedulers and planners for timing and to the production control organization for execution. The plant manufactures lighting products of various shapes, sizes, functions and colors for a full line of cars and trucks for the parent corporation. These range in complexity from simple sidemarker and signal lamps to complex rear lamps. The $2000+$ member workforce is unionized.

Six synchronous cells have been established over the course of the past 18 months. Each of the cells began with a specific product-related proposal describing the cell plan, approved by a joint union-management team. A rough pro-forma cost savings estimate was generated for each cell, projecting cost savings as a result of reduced supervision, increased labor efficiency, lower inventory levels, etc. The estimates definitely reflected $A B C$ thinking, since the projected reductions in quantities of cost drivers consumed were translated into dollar terms. But the estimates suffered from imprecision and were, therefore, viewed with suspicion by some in the plant.

The cells at Auto Light incorporate changes in union work rules. Only two job classifications exist in a cell: "operator" and "job setter." In contrast, the equivalent functions performed in the cell by workers in these two classifications would require as many as six to ten classifications in traditional work centers. Achievement of the "cell operator" or "job setter" classification comes at 45 days, and is based on supervisory evaluation. A 90 day lock-in to the cell assignment applies during cell startup. During this time, operators cannot exercise shift preference to transfer to another department. Operators are expected to be multifunctional, rotating to all jobs within the cell. Cell meetings for problem-solving, continuing job evaluations, and a sense of business ownership are also expected. Training and orientation to cell concepts are provided for supervisors and operators during cell startup. Thereafter, training for new operators coming into the cell is expected to be done by senior operators.

Products manufactured in the cells exhibit high variety both in number and complexity. Number of products ranges from 1 to 18 per cell, with number or operators ranging from 3 to 12. The number of operators is a good proxy for complexity of the products. Ideally, parts are completely fabricated within the cell, with a total in-process material flow distance of 100 feet or less. In practice this ideal is achieved in only two of the existing cells, with the others dependent to some extent on purchased parts or fabricated components made in other, traditionally laid-out areas of the plant. Some robotic handling equipment is in use, but most of the machinery is standalone, with substantial manual intervention required both for production and material movement between machines. The variety of products and processes observed between cells, and even within cells, suggests that $\mathrm{ABC}$ analysis might yield valuable insights into the effects of the new material flows.

Experience with these six cells convinced management that substantial operational resource savings were achievable by moving from the traditional, functional layout to the cell design. The reduction in material flow distance by at least one and possibly two orders of magnitude clearly implied that substantial cost savings ought to be realized. Response time to changes in customer demand was also much faster, a significant strategic value in the volatile automobile market (Blackburn, Elrod, Lindsley and Zahorik (1990)). The lower levels of WIP inventory meant less risk of inventory obsolescence. In addition, expected quality learning rates are faster, because of the proximity in space and time of serial operations (Svaan, Datar and Kekre (1990)). Managers, operators and engineers could now comprehend visually the entire manufacturing process. The cell layout and job rotation policies encouraged teanwork to solve production problens, and enlarged the job scope as well as the knowledge base of the workforce. Cell installations thus 
contributed to "building the learning organization" (Hayes, Wheelwright and Clark (1988)).

The disappointing truth, and the frustration for cell area managers, was that the planned savings were difficult to translate into dollars. Operational measures showed drastic drops in throughput time, floor space, and flow distance, but these savings were not reflected in the plant "Performance to Budget" report. As a result, proposals to expand the scope of the cell manufacturing program came under fire from several quarters. A focus of the controversy was Project 2000 , a cell manufacturing area being designed. It was planned to supply components to a new automotive customer. It is critical to the future of Auto Light to win and retain this business.

The Project 2000 cell incorporated the principles of minimal space, minimal work in process (WIP), minimal throughput time, visual control of inventory, etc. The problem was that planned part costs assigned by the accounting system, especially the overheads, were unacceptably high. The accounting system still assigns the same costs to parts no matter where they are made (e.g., in a cell or in a traditional manufacturing layout). The system implicitly assumed that demands on resources for activities such as supervision, maintenance, inspection, planning, scheduling, material movements and quality assurance would be the same in a cell as in a job shop. It was the consensus of management and the university researchers that to tease out the positive effects of cell manufacturing, the "drivers" of overhead costs had to be understood better, and that new accounting methods (such as activity-based costing (ABC)) could help to quantify the differential consumption of resources under alternative manufacturing layouts.

\section{MATERIAL FLOW AND HANDLING COST ALLOCATION}

A team of faculty and student researchers examined the cost structure at Auto Light as part of a cooperative industry/university research project. The ready availability of data at Auto Light and the cooperation of management made it an ideal industrial research site. The complexity of the operation made the academic connection attractive to management. The phase of research we report here was accomplished in large part by three students over the course of a summer internship under faculty supervision.

The Carnegie Mellon team selected the material handling component of overhead costs as the first cost category to be analyzed, for three reasons. First, it is a major cost category. Second, cell layout should have a considerable impact on this category. Third, material handling seems to affect other categories of costs (such as supervision, quality and planning/scheduling) significantly. The managers wanted to understand the potential cost impact, not reflected by their current accounting systems, of decisions concerning layout, synchronous flow, and vendor certification programs which had eliminated incoming inspection. Each of these decisions alter material flows, which in turn affect the support services and their associated costs.

Material flow patterns in the plant are represented in Figure 2. Note the block of fabrication operations in the upper right portion of the diagram. Virtually all fabricated parts begin with molding. Other operations, if required, typically occur in top-down order (e.g., Mold-AlumPaint-Weld-Stamp). These operations, plus receiving, assembly and shipping represent the value added activities of manufacturing. The inspection, inventory storage and checkpoint blocks are non-value-added (NVA) activities; that is, they add costs but do not transform the products or add features for which customers would be willing to pay. The paid components checkpoint in most cases is a centrally located WIP stacker crane installation, a multi-story automatic storage and retrieval system where inventorics of two types (raw material and WIP) are stored. This means that the flow distance required for most parts manufactured in the traditional, functional 


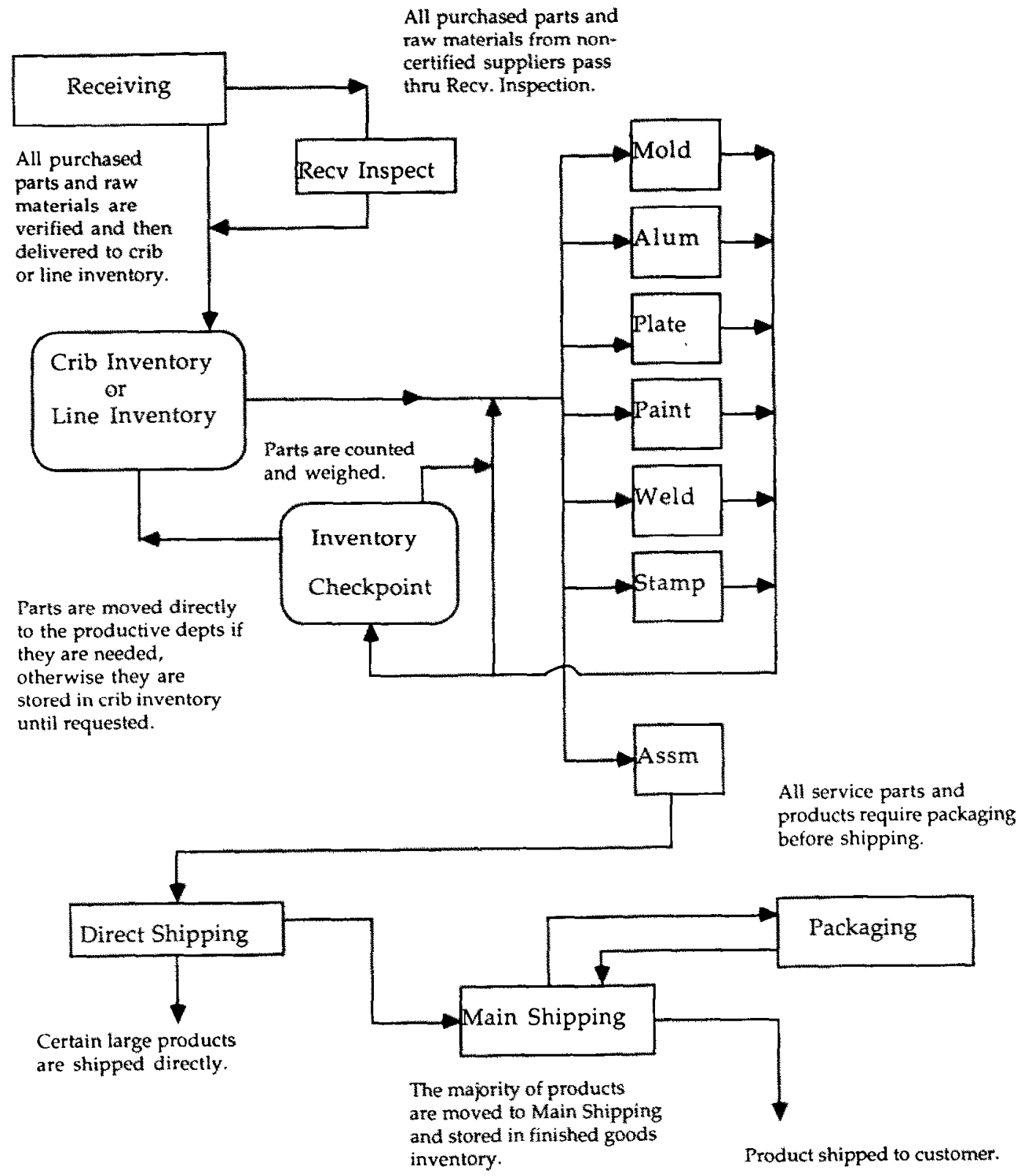


layout is even longer than the path described by a tour of the far-flung operations it must visit for processing. Rather, a part typically moves in "hub and spokes" fashion in and out of the stacker crane an average of five times prior to completion, and is then moved across the street into another stacker to be stored as finished goods inventory until it is shipped to satisfy customer demand.

Cells differ from the dominant process flow illustrated in Figure 2 only in that the value-added operations are grouped together in close physical proximity in a single production area, allowing material to flow smoothly from one machine to another. There is no flow to and from an inventory checkpoint between the operations in a cell, and so material handling and its costs are at a minimum for cell manufactured products. Processes and machinery employed in the cells are at the same level of technology as the remainder of the plant.

Movements between departments are made by fork trucks which handle wirebound bins or pallets. The capacity of the bins/pallets implicitly defines a maximum transfer batch size, which is also effectively a minimum. Material Handling (MH) capacity is a scarce resource which should not be wasted by forcing a truck and driver to pick up partial loads. For certain operations, such as plastic injection molding, this constraint is not usually tight; setup times required for die changes are so long that they dictate larger production batch sizes than the efficient transfer batch sizes. In other cases the transfer batch size does constrain production batch size. Therefore the plant experiences larger WIP inventories and longer lead times than it would without the MH constraints (Karmarkar (1987)).

Handling costs associated with the movement of productive material in the plant amounted to slightly more than $\$ 5,000,000$ in model year 1988 . The total expense associated with $\mathrm{MH}$ of all types (including receiving and shipping, incoming inspection, and movement of nonproductive material) is twice that high, and comprises more than $10 \%$ of the total factory cost of a product. Since these are costs which cell manufacturing is expected to affect substantially, we made a detailed study of these costs. We found that $\mathrm{MH}$ is treated as an overhead item, and that the total cost for all $\mathrm{MH}$ is allocated to products using one of two bases: machine hours or direct labor hours. Machine hour allocation is used consistently for parts whose major operation is molding. These represent approximately 1/3 of the total part count and value added in the plant. Most other parts are allocated MH costs based on their direct labor content. These include operations such as painting, plating, metallizing, hot stamping, welding and assembly.

\section{ACTIVITY-BASED COSTING FOR MATERIAL HANDLING}

The evident distortion introduced by allocation of large $\mathrm{MH}$ costs to cell products led us to study the process "features" (along the lines of Banker et al. (1990), who applied a similar analysis to product features) that drive those costs. We met with managers, operators and staff and generated a long list of plausible drivers of material handling cost. Among them were product features such as dimensions, finish, weight, special care, geometry, etc., as well as the process feature, distance moved, which was determined by the factory layout and production routing. Further investigation revealed that most of the product-related potential cost drivers are insignificant in their impact upon material handling overhead costs. For example, special handling or packing for movement made necessary by unusual part geometry is done by labor within the productive departments, and so is captured in direct labor costs.

The list was eventually trimmed to only two factors: number of moves and distance moved. (For a discussion of the issue of aggregation of cost drivers, see Gupta (1990).) Number of moves was significant because of setup activities required for each move (e.g., handling of the 
paperwork, finding the material, verifying the delivery, etc.) Also, certain expenses such as bin cleaning and repair were found to be move-related (since bin contamination and damage occurred in the process of loading/unloading rather than in transit). Distances per move were highly variable, and both interviews with managers and effort studies confirmed that distance was a highly significant factor in the time and effort required to accomplish each move. It turned out that packing standards for bin/pallet movement are such that all parts required the same degree of care. As long as the weight of a pallet/bin did not exceed the capacity of the fork truck (as was typical), weight was also irrelevant. What mattered, then, was the number of parts contained in each load. This does vary greatly between part numbers, depending on the size of the parts. Smaller parts have many more parts per load than larger ones, and thus should pick up lower unit charges per move.

\section{COST POOL CREATION}

Our analysis of the costs begins with the recognition of three distinct stages of the production process at which material must be handled: purchased parts (raw materials and components), WIP, and finished goods. We collected the costs incurred in 15 departments with material handling responsibilities and assigned them to six cost pools, a move-related and a distancerelated pool for each stage. Examples of departments whose costs are move-related include receiving, incoming inspection, container repair, and carton recycling. In contrast, fork truck maintenance was considered to be distance-related. For some costs, e.g. fork truck driver salaries, we divided the costs between move-related and distance-related pools based on interviews with managers and operators as well as our own time-and-effort observations. In this way the total cost of material handling was subject to a much finer-grained analysis than was possible with a single large cost pool. Our system also contains inherent distortions, since we have allocated the many overheads in the cost pools on the basis of only six drivers (two at each of the three stages) rather than assigning a unique driver for each cost item. However, in our judgment and in the opinion of Auto Light personnel, the distortion levels are much lower than those imposed by the previous allocation system.

\section{ASSIGNMENT OF COSTS TO PARTS}

Each part in active production (approximately 200) was entered into a material handling data base. This data base included parts made in cells as well as those produced in traditional fashion in many different functional departments. This data base contained fields for weight, dimensions, annual volume, and production routing. Weight was necessary because it determined the amount of raw material and raw material handling needed for production. Dimensions determined the fraction of a load represented by the part. Annual volume times the fraction of a load per part determined the total number of loads (= number of moves) annually. The production routing specified the departments in the plant through which the part passed during production. Some of this information was available in electronic form from company data bases, some was read from engineering drawings and production routing sheets, and some was obtained by visually observing and measuring the parts themselves.

One critical but time-consuming task of the study was the creation of a file containing data on the location ( $\mathrm{X}$ and $\mathrm{Y}$ coordinates of bay numbers) of each department. This information was transferred from plant layout diagrams and observation on the plant floor. Next, all observed pairs of consecutive departments were entered with the rectilinear distance expressed in bay 
numbers (a reasonable approximation of transit distance, since trucks used aisles that are laid out on grid) and number of moves typically required. An example is: from department $A$ to department $\mathrm{B}$ requires 3 moves and a distance of 15 bays. This consists of a move from department $\mathrm{A}$ to an inventory checkpoint, from the checkpoint to crib inventory, and from crib inventory to department $B$.

Once this data was entered, it was a straightforward calculation to sum the total distance traveled by all loads and divide this into the distance-related cost pool for purchased part, WIP and finished goods stages to find the cost per distance factor index. Similarly, the total moves for all parts were divided at each of the first two stages into the move-related cost pool to find the cost per move factor index. Table 2 exhibits the calculations and the overhead rates that apply to the three movement factor indices and the three distance factor indices.

TABLE 2

CALCULATING MATERIAL HANDLING OVERHEAD RATES

\begin{tabular}{lcccccc}
\hline & \multicolumn{7}{c}{$\begin{array}{c}\text { Factor Index } \\
\text { Move }\end{array}$} & $\begin{array}{c}\text { Move } \\
\text { Purch } \\
\text { (M1) }\end{array}$ & $\begin{array}{c}\text { Move } \\
\text { (M2) }\end{array}$ & $\begin{array}{c}\text { FG } \\
\text { (M3) }\end{array}$ & $\begin{array}{c}\text { Dist } \\
\text { Purch } \\
\text { (D1) }\end{array}$ & $\begin{array}{c}\text { Dist } \\
\text { WIP } \\
\text { (D2) }\end{array}$ & $\begin{array}{c}\text { Dist } \\
\text { FG } \\
\text { (D3) }\end{array}$ \\
\hline Stage Cost $(000)$ & $\$ 156$ & $\$ 572$ & $\$ 364$ & $\$ 624$ & $\$ 2,288$ & $\$ 1,248$ \\
Fact Index Sum & 39,000 & 220.000 & 69,000 & 1.040 .000 & 2.514 .000 & 1.522 .000 \\
Overhead Rate & $\$ 4.00$ & $\$ 2.60$ & $\$ 5.27$ & $\$ 0.60$ & $\$ 0.91$ & $\$ 0.82$ \\
\hline
\end{tabular}

Several features of the table deserve comment. First, it is not the case that it costs the same to pick up a load everywhere. Therefore the factors that apply the drivers, and the drivers themselves, are unique at each stage. The per-move costs of purchased part movements are higher than those of WIP movements. Neither is it the case that distance is the same everywhere. Finished goods distance is less expensive than WIP distance, and both are more expensive than purchased parts. We cannot explain fully those differences, but we do observe that the direction of the differences is plausible. Purchased part movements begin at a single point, and finished goods movements end at a single point. Thus these handlings exhibit a one-to-few structure that is conspicuously missing from the many-to-many moves between departments for WIP. The finished goods movements are complicated by the fact that they go across the street. It could be the case that the assumption made throughout that full loads are being transported may be violated, especially in the WIP and finished goods stages. It is possible also that real efficiency differences exist in the MH operations at the three stages, which may be an appropriate subject for managerial follow-up.

\section{COMPARISON OF OLD VERSUS NEW COSTS}

We next analyzed old costs versus new costs in aggregate terms. The first investigation was a linear regression of our new material handling cost ("NEWCOST") against the old cost allocation basis, machine hours ("MHRS"). The regression output appears in Table 3 . We noted that the adjusted $\mathrm{R}^{2}$ value of .404 indicated a significant divergence between the old cost basis and the new cost. If the correlation had been very high between the old cost basis and the new cost ( $\mathrm{R}^{2}$ close to 1.00$)$, there would be no product costing reason to adopt our new cost system. 
The actual discrepancy indicates a serious mismatch between the costs of material handling we identified and the current allocation basis.

TABLE 3

REGRESSION OF NEWCOST VS MACHINE HOURS (MHRS)

\begin{tabular}{|c|c|c|c|c|}
\hline $\begin{array}{l}\text { Dependent Variable } \\
\text { Number of Observati } \\
\text { Variable }\end{array}$ & Coefficient & Std. Error & T-stat & 2-Tail Sig. \\
\hline CONSTANT & -1457.238 & 680.798 & -2.141 & 0.032 \\
\hline MHRS & 3.905 & 0.262 & 14.906 & 0.000 \\
\hline $\begin{array}{l}\text { R-Squared } \\
\text { Adj R-Squared } \\
\text { Std. Error Regression } \\
\text { F-Statistic }\end{array}$ & & $\begin{array}{r}0.406 \\
0.404 \\
9346.654 \\
222.1961\end{array}$ & & \\
\hline
\end{tabular}

We note that the regression does show that MHRS is a very significant independent variable in the NEWCOST regression $\left(T_{327}=14.906, p<0.001\right)$. This reflects the fact that, apart from products manufactured in cells, there is a dominant process flow in the plant as represented in Figure 2, most traditionally-manufactured parts travel similar distances in the plant. Since physical size (which determines the annual number of loads of each part required between each pair of manufacturing departments) and molding machine hours are closely correlated, MHRS turns out to be a fairly good allocation basis for standard parts manufactured in the functional layout. Its weakness is its inability to attribute move-related and distance-related cost savings properly to advanced manufacturing processes with rationalized process flows.

\section{EXAMPLE: CELL VERSUS NON-CELL PRODUCT COST}

An example is shown in Table 4 of how the material handling costs of an individual part made in a cell are applied under the old and the new costing systems.

Products A and B are representative Cell and Non-cell products, constructed to be identical in all respects except in the process layout utilized for their manufacture. Traditional Material Handling overhead allocation charges them both with $\$ 20,000$ in annual costs, based on their identical unit volume and identical machine hours.

$\mathrm{ABC}$ costing tells a very different cost story. It takes into account the demands upon the material handling operation placed by the parts. Note that the handling required for Purchased part movements and finished good movements are identical; the only difference between the two is in number of moves and distance moved as WIP. Cell product A, with its value added operations located in a single department, requires WIP material handling by the production control department for only two moves, i.c. of raw material from the inventory checkpoint and of finished parts to the inventory checkpoint. The $\mathrm{ABC}$ cost of handling Product $\mathrm{A}$ is only $\$ 0.23$ per unit, while the $A B C$ cost of handling Product $B$ is $\$ 0.90$ per unit. Note that the annual costs calculated by the $\mathrm{ABC}$ method do not total to the same sum as those calculated by the traditional method, because there are other parts in the system whose costs also are distorted.

The cost of Product A under the traditional allocation was overstated by $\$ 0.27 /$ unit. Based on the fact that overall $\mathrm{MH}$ costs make up roughly $10 \%$ of total factory cost (under the current 
TABLE 4

OLD VS NEW COST FOR TYPICAL CELL AND NON-CELL PRODUCTS

\begin{tabular}{|c|c|c|c|}
\hline \multicolumn{2}{|c|}{ Part information } & $\begin{array}{c}\text { Cell } \\
\text { Prod A }\end{array}$ & $\begin{array}{l}\text { Non-cell } \\
\text { Prod B }\end{array}$ \\
\hline \multicolumn{2}{|c|}{ Annual volume } & 40,000 & 40,000 \\
\hline \multicolumn{2}{|c|}{ Machine Hours/unit } & 0.05 & 0.05 \\
\hline \multicolumn{2}{|c|}{ Parts/load } & 200 & 200 \\
\hline Moves: & Purchased part & 2 & 2 \\
\hline \multirow[t]{2}{*}{$(\#)$} & WIP & 2 & 12 \\
\hline & Fin Good & 2 & 2 \\
\hline \multirow{3}{*}{$\begin{array}{c}\text { Distance: } \\
\text { (bays) }\end{array}$} & Purchased part & 12 & 12 \\
\hline & WIP & 5 & 125 \\
\hline & Fin Good & 12 & 12 \\
\hline \multicolumn{4}{|c|}{ Traditional Material Handling Overhead allocation: } \\
\hline \multicolumn{2}{|c|}{ Machine hours rate: } & $\$ 10.00$ & $\$ 10.00$ \\
\hline \multicolumn{2}{|c|}{ Unit overhead applied } & $\$ 0.50$ & $\$ 0.50$ \\
\hline \multicolumn{2}{|c|}{ Annual volume } & 40,000 & 40,000 \\
\hline \multicolumn{2}{|c|}{ Annual total $\mathrm{MH}$ overhead } & $\$ 20,000.00$ & $\$ 20.000 .00$ \\
\hline \multicolumn{4}{|c|}{ ABC Material Handling overhead allocation: } \\
\hline \multicolumn{2}{|c|}{ Annual volume } & 40,000 & 40,000 \\
\hline \multicolumn{2}{|l|}{ Parts/load } & 200 & 200 \\
\hline \multicolumn{2}{|c|}{ Annual loads } & 200 & 200 \\
\hline \multirow[t]{3}{*}{ Moves: } & M1 rate & $\$ 4.00$ & $\$ 4.00$ \\
\hline & M2 rate & $\$ 2.60$ & $\$ 2.60$ \\
\hline & M3 rate & $\$ 5.27$ & $\$ 5.27$ \\
\hline \multirow[t]{3}{*}{ Distance: } & D1 rate & $\$ 0.60$ & $\$ 0.60$ \\
\hline & D2 rate & $\$ 0.91$ & $\$ 0.91$ \\
\hline & D3 rate & $\$ 0.82$ & $\$ 0.82$ \\
\hline \multirow[t]{6}{*}{ Extension: } & M1*loads*moves & $\$ 1,600.00$ & $\$ 1,600.00$ \\
\hline & M2*loads*moves & $\$ 1,040.00$ & $\$ 6.240 .00$ \\
\hline & M3*loads*moves & $\$ 2,108.00$ & $\$ 2,108.00$ \\
\hline & D $1 *$ loads*distance & $\$ 1,440.00$ & $\$ 1.440 .00$ \\
\hline & $\mathrm{D} 2 *$ loads*distance & $\$ 910.00$ & $\$ 22,750.00$ \\
\hline & D3*loads*distance & $\$ 1,968.00$ & $\$ 1,968.00$ \\
\hline \multicolumn{2}{|c|}{ Annual total MH overhead } & $\$ 9,066.00$ & $\$ 36,106.00$ \\
\hline \multicolumn{2}{|c|}{ MH overhead/unit } & $\$ 0.23$ & $\$ 0.90$ \\
\hline
\end{tabular}

accounting system), and that the average factory cost of products at Auto Light is around $\$ 5.00$, this $\$ 0.27$ probably represents $5 \%-6 \%$ of the unit factory cost of Product A. Nor is this documented distortion the end of the story: in preliminary studies conducted by the authors at this and other sites, we have observed overall cost distortions on the order of 20-30\%. This overstatement of costs could lead to attack by a focused competitor. More likely to do damage to Auto Light, though, is the faulty signal that the traditional accounting system sends to managers concerning the cost profile of products manufactured in cells. The inference that a manager would draw from the traditional $\mathrm{MH}$ allocation shown in Table 4 is that the investment in process redesign has not paid financial benefits. Only when $\mathrm{MH}$ resource consumption is traccd via cost drivers to the products being handled do the cost savings of process redesign emerge for managerial scrutiny. 
For Product A, the cost savings of the cell layout for purposes of process design choice should actually be calculated not by comparison to the traditional cost but to the cost of the alternative. functional layout. Therefore the annual savings for Product $A$ is not $(\$ 20,000-\$ 9,066)$ but rather $(\$ 36,106-\$ 9,066)$. The relevant unit cost saving is the difference between $\$ 0.90$, the cost of material handling in a functional layout, and $\$ 0.23$, the cost of material handling in a cell layout. This number, multiplied by the number of products produced in each cell, gives the annual savings contributed by that cell. The plant-wide total amounts to hundreds of thousands of dollars-all unrecognized by the plant report. And so managers receive conflicting signals about cell implementation success. Until the cost distortions are eliminated, process improvements may have to be "justified by faith alone" (Kaplan (1986)).

Note that the cost rollup under $\mathrm{ABC}$ for material handling is more complicated than the traditional method (the number of lines in the spreadsheet alone is a fair, though imperfect, indicator of the complexity of the method.) Because of the fact that multiple cost pools are more intensive in both information and computation than traditional unitary pools, use of computerized data processing was a necessary prerequisite for the deployment of $\mathrm{ABC}$ as a working cost system. The tremendous technological advances in computing that have made hardware, memory and software so plentiful and cheap today have given economic feasibility to costing systems which would have been prohibitively expensive when green eyeshades and ledger paper were the state-of-the-art accounting tools.

\section{DRIVERS INTO DOILARS}

Returning to the scenario of Table 4 we can ask the question, "What happens when traditional overhead allocation is replaced by ABC?" Ideally, management would notice the higher costs associated with handling for product $B$ and search for ways to bring its handling costs into line with those of product $\mathrm{A}$. This could lead to reduction of the total material handling trips to 200,000 from the original 500,000 . By itself this will not reduce expenditures in the short term. But it creates the opportunity for future cost reductions. The exercise that we have done is not merely reallocation of existing costs, but identification of opportunities for cost elimination and avoidance. For example, the difference in unit cost of material handling between A's $\$ 0.23$ and B's $\$ 0.90$ represents an opportunity for saving of $\$ 0.67$ per unit of B produced that could be realized by process reorganization.

Our research has documented the reduced demand placed on material handling resources by cell manufacturing compared to the previous process layout at Auto Light. Actual dollar savings are much harder to document. Three factors make it impossible to demonstrate actual dollar savings in our studies so far. The first is the static business environment; the second is the continued use of the traditional accounting system; the third is the "sticky" nature of costs. Auto Light employs a union workforce in the static domestic auto industry. This helps to make many costs "sticky" on the downward side, at least in the short term. For example, laid-off workers must be-paid most of their salary, benefits and insurance. Occupancy costs vary little with volume. Reduced wear-and-tear of pallets, bins and fork trucks may defer future purchases but mean little in the short term. Neither is Auto Light facing increases in demand for its products which would necessitate acquisition of more equipment and the hiring of more workers in the near future.

Figure 3 illustrates the relationship between cell implementation, driver reduction and cost savings. We find that cell implementation leads quickly and automatically to driver reduction (Link A). On the other hand, driver reduction may take explicit managerial intervention and 
FIGURE 3

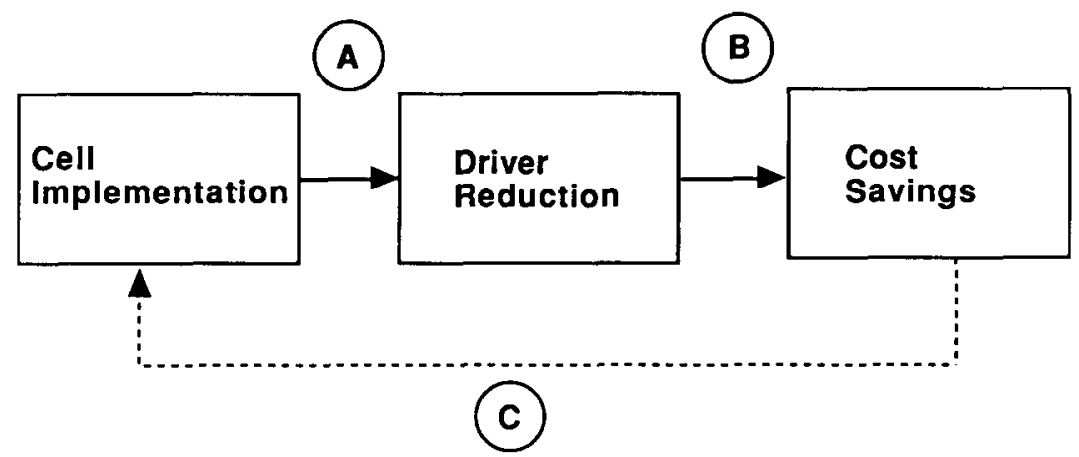

Link A, cell implementation to driver reduction, is direct and immediate.

Link $\mathrm{B}$, driver reduction to cost savings, is a function of resource allocation, growth profile, and time.

Link C, perceived cost savings due to cell implementation, is a function of accounting system accuracy. It is likely to be delayed and noisy even in $\mathrm{ABC}$ environments.

elapsed time to produce cost savings (Link B). The accounting information system must send the right signals to managers concerning the effects of the simplified material flows (Link C).

The material handling savings we have shown in fact represent an upper bound on the actual dollars whose expenditure may be avoided over time by the use of rationalized material flow through cell organization. It is possible that the "savings" have heen turned into organizational slack in the production control department. What the $\mathrm{ABC}$ analysis can do is to focus management attention on the process features that create costs, rather than diffusing the attention by spreading the costs to products on a naive basis.

\section{CONCLUSIONS}

We have reported on the quantification of the benefits of cell manufacturing using activitybased costing. We presently are in continuing discussions with managers of Auto Light company concerning the implementation of a new cost accounting system which will be fully activity based, using the Project 2000 cell area as the test site. The outcome of the experiment may lead to a full-scale implementation of $\mathrm{ABC}$ at Auto Light, probably as a supplement to rather than a replacement for the traditional accounting systems. The traditional systems are needed for interfacing with corporate reporting, and so must continue to be maintained. But the $\mathrm{ABC}$ systems will provide decision support to product designers, process designers and managers by reporting accurately in financial terms the very real advantages of innovative manufacturing practices. By doing so, they will lay the foundation for competitive advantage for Auto Light in the decade to comc. 


\section{ACKNOWLEDGEMENTS}

The authors wish to express their deep appreciation to the managers and workers of Auto Light company whose cooperation made this research possible, to research assistant Edmund Connor who collected and processed much of the data, and especially to the Special Issue Editor and three anonymous reviewers who made many helpful suggestions to improve this paper.

\section{REFERENCES}

Banker, R. S. Datar, S. Kekre. and T. Mukhopadyay. "Cost of Product and Process Complexity." In Measures for Manufacturing Excellence, R. Kaplan (ed.) Boston: Harvard Business School Press, 1990, 269-290.

Berlant, D., R. Browning, and G. Foster. "How Hewlett-Packard Gets Numbers It Can Trust." Harvard Business Review; vol. 68, no. 1, January-February 1990, 178183.

Blackburn, J., T. Elrod, W. Lindsley, and A. Zahorik. "The Strategic Value of Response Time and Product Variety." Paper submitted to the Fifth International Conference on Manufacturing Strategy, University of Warwick. England. June 1990

Cooper, R. "The Rise of Activity-based Costing. Part One: What Is an Activity-Based Cost System?" Journal of Cost Management, vol. 2, no. 2, Summer 1988, 45-54.

Cooper, R. "Part Two: When Do 1 Need an Activity-based Cost System? Journal of Cost Management, vol. 2, no. 3, Fatl 1988, $41-48$.

Cooper, R. "Part Three: How Many Cost Drivers Do You Need and How Do You Select Them?" Journal of Cost Management, vol. 2, no. 4, Winter 1989, 34-46.

Cooper, R. "Part Four: What Do Activity-based Cost Systems Look Like?"” Journal of Cost Management, vol. 3, no. 1, Spring $1989,38-49$.

Cooper, R. (ed.) "Activity-based Costing." Journal of Cost Management, Special Issue., vol. 4, no. 1, Spring 1990.

Cooper, R. and R. Kaplan. "Measure Costs Right: Make the Right Decisions." Harvard Business Review, vol. 66, no. 5, September-October 1988, 96-103.

Cooper, R., and P. Turney. "Internally Focused Activity-based Cost Systems." In Measures for Manufacturing Excellence. R. Kaplan (ed.) Boston: Harvard Business School Press, 1990, 291-308.

Cooper, W., K. Sinha, and R. Sullivan. "Accounting for Complexity in Costing High-Technology Production." Working paper, University of Texas at Austin, November 1990.

Foster, G., and M. Gupta. "Activity Accounting: An Electronics Industry Implementation." In Measures for Manufacturing Excellence, R. Kaplan (ed.) Boston: Harvard Business School Press, 1990, 225-268.

Gupta. M. "Aggregation Issues in Product Costing." Working Paper, Graduate Business School, Stanford University, 1990.

Hayes. R., S. Wheelwright, and K. Clark. Dynamic Manufacturing. New York: The Free Press, 1988.

Hyer, N., and U. Wemmerlöv. "Group Technology and Productivity." Harvard Business Review, vol. 64, no. 2, JulyAugust 1984, 140-149.

Hyer, N., and U. Wemmerlöv. "Group Technology in the U.S. Manufacturing Industry: A Survey of Current Practices." International Journal of Production Research, vol. 27, no. 8, August 1989, 1287-1304.

Jaikumar, R. "An Architecture for a Process Control Costing System." In Measures for Manufacturing Excellence, R. Kaplan (ed.) Boston: Harvard Business School Press, 1990, 193-224

Johnson, T., and R. Kaplan. Relevance Lost: The Rise and Fall of Management Accounting. Boston: Harvard Business School Press, 1987.

Karmarkar, U. "Lot Sizing, Manufacturing Lead Times and Utilization." Management Science, vol 33, no. 3, March 1987, 409-418.

Kaplan, R. "Management Accounting for Advanced Technological Environments." Science, vol. 245, August 1989, $819-823$

Kaplan, R. "Must CIM Be Justified by Faith Alone?" Harvard Business Review, vol. 64, no. 2 March-April 1986. 87-96.

Kaplan, R. (ed.) Measures for Manufacturing Excellence. Boston: Harvard Business School Press, 1990.

Kaplan, R., and A. Atkinson. Advanced Management Accounting. 2nd ed. Englewood Cliffs, NJ: Prentice-Hall, 1989, $p$ 195.

March. A. "John Deere Component Works." Harvard Business School Case 9-187-107, 1987.

Shank, J., and V. Govindarajan. "Transaction-based Costing for the Complex Product Line: A Field Study." Journal of Cost Management, vol. 2. no. 2. Summer 1988, 31-38. 
Stalk, G. "Time-The Next Source of Competitive Advantage." Harvard Business Review, July-August 1988, 41-51. Svaan, E., S. Datar, and S. Kekre. "Learning Effects in Cell Manufacturing". In Manufacturing Strategy, J. Ettlie, M. Burstein, and A. Feigenbaum (eds.) Norwell, Mass: Kluwer, 1990, 75-84.

Wemmerlöv, U., and N. Hyer. "Cellular Manufacturing in the U.S. Industry: A Survey of Users." International Journal of Production Research, vol. 27, no. 9, September 1989, 1511-1530. 